\title{
GC-MS Analysis of $\mathbf{n}$-hexane Extract of Stem Bark of Symplocos crataegoides Buch.-Ham. ex D. Don
}

\author{
Nartunai Govindarajan ${ }^{1 *}$, Uma Maheswara Reddy Cheekala², Shantha Arcot ${ }^{3}$,Susikumar Sundaramoorthy', \\ Ramasamy Duraisamy ${ }^{4}$, llavarasan Raju ${ }^{5}$
}

\section{Nartunai Govindarajan ${ }^{1 *}$, Uma Maheswara Reddy Cheekala ${ }^{2}$, Shantha Arcot ${ }^{3}$, Susikumar Sundaramoorthy', Ramasamy Duraisamy ${ }^{4}$, llavarasan Raju ${ }^{5}$}

\author{
'Department of Pharmacognosy, \& \\ ${ }^{5}$ Department of Pharmacology Captain \\ Srinivasa Murthy Regional Ayurveda \\ Drug Development Institute, CCRAS, \\ Govt. of India, Arumbakkam, Chennai- \\ 600 106, Tamil Nadu, INDIA. \\ 2Department of Pharmacology, Sri \\ Ramachandra College of Pharmacy, \\ Sri Ramachandra University, Porur, \\ Chennai -600116, Tamil Nadu, INDIA. \\ ${ }^{3}$ Department of Pharm. Analysis, \\ C.L.Baid Metha College of Pharmacy, \\ Thoraipakkam, Chennai-600 097, \\ Tamil Nadu, INDIA. \\ ${ }^{4}$ Department of Chemistry, Govt. Arts \\ College, Ariyalur - 621 713, Tamil Nadu, \\ INDIA.
}

\section{Correspondence}

Nartunai Govindarajan, Department of Pharmacognosy, Captain Srinivasa Murthy Regional Ayurveda Drug Development Institute, CCRAS, Govt. of india, Arumbakkam, Chennai - 600 106, Tamil Nadu, INDIA.

Email: natrunai@yahoo.co.in DOI : 10.5530/pj.2016.6.2

Article Available online

http://www.phcogj.com/v8/i6

Copyright

(C) 2016 Phcog.Net. This is an open-access article distributed under the terms of the Creative Commons Attribution 4.0 International license.

\begin{abstract}
Context: The stem barks of the plant Symplocos crataegoides Buch.-Ham. ex D. Don (syn. Symplocos paniculata (Thunb.) Miq.), Fam. Symplocaceae is extensively used in Indian medicine under the names of Lodhra/Patikalodhra. Mainly it is used to cure uterine complaints, vaginal and menstrual disorders. Aim: To investigate the phytochemicals from the n-hexane extract of the stem bark of Symplocos crataegoides Buch.-Ham. ex D. Don., using GC-MS analysis. Materials and Methods: Stem bark of S.crataegoides was extracted by Soxhlet extraction method using $n$-hexane. The extract was injected by splitless injection mode into the GC MS 5975 C Agilent equipped with a QP- 5000 (quadrupole) Gas Chromatography - Mass Spectrometer. Results: Identification of 57 compounds from n-hexane extract. Those compounds were identified by close matches with standard MS spectra and compared with NIST - 11 and WILEY library data. Undecane $(7.51 \%)$ was found as major compound followed by Isopropyl myristate, Dodecane, 1,2,4-trimethyl-benzene, Octacosane, 2-methyl-decane, 2-ethyl-1,2-dimethyl-benzene, $1,2,3,5$ - tetramethyl-benzene etc., other constituents were found to be in traceable quantities. Conclusion: GC-MS analysis of $S$. crataegoides revealed certain interesting facts of presentation of various phytoconstituents in the stem bark. The presence of various phytoconstituents contributes to the medicinal activity of the plant.
\end{abstract}

Key words: Symplocos Crataegoides, Patikalodhra, GC-MS Analysis, n-hexane extract.

\section{INTRODUCTION}

The stem bark of the plant Symplocos crataegoides Buch.-Ham. ex D. Don, Fam. Symplocaceae is extensively used in Indian medicine under the names of Lodhra/Patikalodhra. S. crataegoides is a deciduous shrub or a tree, distributed in the Himalayas from Punjab to Assam, Khasi hills and Burma. ${ }^{1,2}$ As per Ayurvedic references the term Lodhra denotes the stem bark of Symplocos racemosa/Symplocos crataegoides and considered as most useful remedy for uterine complaints, vaginal and menstrual disorders. In Sanskrit the name Lodhra means that it stops ocular discharges. The drug is useful in digestive disorders, eye diseases and ulcers. Decoction of the bark is used as a gargle in bleeding gums. Its astringent property is utilized for curing loose motions. It is used as aphrodisiac, useful in dropsy, elephantiasis and in fat in urine (Lipiduria). The bark is used in the treatment of opthalmia, tonic and to prevent abortion. ${ }^{1,3-7}$ The important Ayurvedic formulations in which Lodhra is used as one of the ingredients are Lodhrasavam, Gandhatailam, Dasamularistam, Draksadi kasayam, Pusyanugacurnam, etc. ${ }^{8}$ The Nyagrodhadi Kvatha Curna contains both Symplocos racemosa and Symplocos crataegoides as ingredients and Nyagrodhadi curna contain only Symplocos racemosa. ${ }^{9}$

Most of the Books on Indian Materia Medica equate Symplocos racemosa as well as S. crataegoides as the botanical source of Lodhra or Rodhra. ${ }^{2}$ Two varieties of Lodhra are described in the texts viz. Sabara lodhra and Patika lodhra. Sabara lodhra is equated with Symplocos racemosa and Patika lodhra is equated with Symplocos crataegoides. ${ }^{8}$ Botanically S. racemosa and S. crataegoides are different species called by similar vernacular name Lodhra. The petroleum ether $\left(60-80^{\circ}\right)$ extract of leaves of Symplocos crataegoides shows the presence of Octacos-1-ene, Stigmasterol and Lupeol, whereas ethanolic extract yields Salirepin. ${ }^{10}$ The following compounds isolated from the ethanolic extract of the stem bark of Symplocos crataegoides (syn: S. paniculata) were reported. 4-(8-hydroxyethyl) cyclohexan-1-oic acid; androst-5(6)-ene 17-one $3 \beta$-O-( $\beta$-D-glucopyranoside); 9 $\beta$, 25-cyclo $3 \beta$-O- $(\beta-\mathrm{D}$ glucopyranosyl)-echynocystic acid; $9 \beta, 19$-cyclo 24-methylcholan-5,22-diene 3 $\beta$-O-( $\beta$-D-glucopyranosyl (1---6) $\alpha$-D-rhamnopyranoside); 30 -Et $2 \alpha, \quad 16 \alpha-$ dihydroxy 33-O- ( $\beta$-D-glucopyranosyl) hopan-24-oic acid;32,33,34-trimethyl-bacteriohopan-16-ene3-O- $\beta$-Dglucopyranoside; and flavones 3,4,'5, 6'-tetramethoxy 
Table 1: GC-MS Data of $\mathbf{n}$-hexane extract of stem bark of S. crataegoides Buch.-Ham. ex D. Don

\begin{tabular}{|c|c|c|c|c|}
\hline $\begin{array}{l}\text { Identified Peak } \\
\text { No }\end{array}$ & $t_{R}$ (Mins.) & Name of the compound & peak area \% & SI factor (\%) \\
\hline 1 & 6.141 & Mesitylene & 1.18 & 95 \\
\hline 2 & 6.617 & 1,3-diethyl -benzene & 0.83 & 91 \\
\hline 3 & 6.683 & 1-methyl-3-propyl benzene & 1.53 & 93 \\
\hline 4 & 6.899 & 2-methyl-decane & 2.28 & 90 \\
\hline 5 & 6.951 & 1-methyl-2-propyl-benzene & 0.59 & 92 \\
\hline 6 & 7.010 & 3-methyl decane & 1.57 & 92 \\
\hline 7 & 7.144 & 2-ethyl-1,4-dimethyl benzene & 0.74 & 97 \\
\hline 8 & 7.196 & O-cymene & 1.00 & 95 \\
\hline 9 & 7.315 & 2-ethyl-1,2-dimethyl-benzene & 2.01 & 94 \\
\hline 10 & 7.567 & Undecane & 7.51 & 90 \\
\hline 11 & 7.679 & 4-ethyl-1,4-dimethyl-benzene & 0.58 & 95 \\
\hline 12 & 7.924 & 2-methyl-trans-decalin & 1.20 & 97 \\
\hline 13 & 7.961 & 1,2,3,4-tetramethyl-benzene & 0.94 & 95 \\
\hline 14 & 8.021 & 3,7-dimethyl-decane & 0.76 & 90 \\
\hline 15 & 8.214 & 1-methyldecahydronaphthalene & 0.69 & 92 \\
\hline 16 & 8.243 & Pentyl- cyclohexane & 0.53 & 94 \\
\hline 17 & 8.526 & $1,2,3,5$ - tetramethyl-benzene & 2.0 & 94 \\
\hline 18 & 8.555 & 1,2-bis(1-methylethyl)-benzene & 0.94 & 93 \\
\hline 19 & 8.600 & 4-methyl-undecane & 0.65 & 91 \\
\hline 20 & 8.689 & 2-methyl-undecane & 1.00 & 93 \\
\hline 21 & 8.801 & 3-methyl-undecane & 0.91 & 90 \\
\hline 22 & 8.890 & 1,2,4-trimethyl-benzene & 3.24 & 92 \\
\hline 23 & 9.187 & Azulene & 1.67 & 91 \\
\hline 24 & 9.313 & Dodecane & 4.60 & 93 \\
\hline 25 & 9.514 & 3,6-dimethyl-undecane & 1.21 & 90 \\
\hline 26 & 10.465 & 2,6-dimethyl-octane & 0.99 & 90 \\
\hline 27 & 10.918 & Tridecane & 1.65 & 98 \\
\hline 28 & 11.014 & 2-methyl-naphthalene & 0.32 & 96 \\
\hline 29 & 12.411 & Tetradecane & 0.61 & 98 \\
\hline 30 & 13.800 & Pentadecane & 0.34 & 98 \\
\hline 31 & 15.100 & Hexadecane & 0.44 & 97 \\
\hline 32 & 16.333 & Heptadecane & 0.18 & 98 \\
\hline 33 & 17.507 & Octadecane & 1.14 & 98 \\
\hline 34 & 17.767 & Isopropyl myristate & 7.45 & 94 \\
\hline 35 & 19.505 & Butyl myristate & 0.33 & 98 \\
\hline 36 & 19.676 & Eicosane & 1.71 & 98 \\
\hline 37 & 21.504 & Hexadecanoic acid butyl ester & 1.09 & 99 \\
\hline 38 & 21.652 & Docosane & 1.50 & 95 \\
\hline 39 & 23.071 & Octatriacontyl pentafluoropropionate & 0.20 & 90 \\
\hline 40 & 23.338 & Octadecanoic acid -2-methylpropyl ester & 0.65 & 90 \\
\hline 41 & 23.465 & Tetracosane & 1.24 & 98 \\
\hline 42 & 23.524 & 2,6,10,14-tetramethyl-hexadecane & 0.24 & 94 \\
\hline 43 & 24.081 & Tricosane & 0.28 & 95 \\
\hline 44 & 24.319 & Heneicosane & 0.49 & 95 \\
\hline 45 & 24.601 & 2-(octadecyloxy)-ethanol & 0.89 & 90 \\
\hline 46 & 24.921 & 1-iodo-hexadecane & 0.59 & 95 \\
\hline
\end{tabular}


Table 1: Contd.

\begin{tabular}{ccccc}
\hline $\begin{array}{c}\text { Identified Peak } \\
\text { No }\end{array}$ & $t_{R}$ (Mins.) & Name of the compound & peak area \% & SI factor (\%) \\
\hline 47 & 25.144 & 1-bromo-octadecane & 1.49 & 91 \\
48 & 25.188 & Nonahexacontanoic acid & 0.37 & 93 \\
49 & 25.426 & 1-Hexacosene & 0.60 & 95 \\
50 & 25.723 & Hexacosane & 0.59 & 95 \\
51 & 26.176 & 1-iodo-octadecane & 0.46 & 91 \\
52 & 26.221 & 1-bromodocosane & 0.87 & 9.77 \\
53 & 26.741 & Octacosane & 1.86 & 93 \\
54 & 28.642 & 1-chloro-heptacosane & 1.72 & 91 \\
55 & 29.816 & Hentriacontane & 1.22 & 91 \\
57 & 31.205 & Nonacosane & 0.92 & 90 \\
\hline
\end{tabular}

7-O- $\beta$-D-glucopyranosyl (1---3) $\beta$-D-glucopyranoside. ${ }^{11}$ The present investigation is carried out to determine the possible chemical components of $\mathrm{n}$-hexane extract of stem bark of $S$. crataegoides by GC-MS analysis.

\section{MATERIALS AND METHODS}

\section{Procurement of Plant Materials}

The authentic samples of stem bark of Symplocos crataegoides Buch.Ham. ex D. Don. (Figure 1) was supplied by Dr.G.C.Joshi, Research Officer, Regional Research Institute of Himalayan Flora, CCRAS, Thapala, Ranikhet - 263645, Almora dist., Uttarakhand. The museum specimen (C/222B SB26) is deposited in the department of Pharmacognosy, Captain Srinivasa Murthy Regional Ayurveda Drug Development Institute, Arumbakkam, Chennai, India for future reference.

\section{Preparation of Extract}

The shade dried and coarsely powdered (10/44) stem bark of $S$. crataegoides ( $4 \mathrm{~g}$ ) were extracted using $\mathrm{n}$-hexane (AR) by soxhlet extraction method. The extract was filtered through Whatman No.1 filter paper and concentrated in vacuum to constant weight. The yield of the extract is $0.4 \%$. The $n$-hexane extract of the plant was used for GC-MS analysis.

\section{Gas Chromatography - Mass Spectrometer Conditions}

Gas chromatography combined with mass spectroscopy is a preferable methodology for routine analysis of compounds. n-hexane extract was injected by split less injection mode into the GC MS 5975 C Agilent equipped with a QP- 5000 (quadrupole) mass spectrometer, fitted with a DB -5 MS ultra inert $30 \mathrm{~m}$ x $250 \mu \mathrm{m}$, film thickness $0.25 \mu \mathrm{m}$ capillary GC column, coated with polydimethyl siloxane. Helium was the carrier gas at a flow rate of $1.5 \mathrm{ml} / \mathrm{min}$. The injector port temperature was $250^{\circ} \mathrm{C}$, the detector temperature was $250^{\circ} \mathrm{C}$ and the oven temperature was maintained at $70^{\circ} \mathrm{C}$ for $3 \mathrm{mins}, 10^{\circ} \mathrm{C} / \mathrm{min}$ up to $300^{\circ} \mathrm{C}$ for 9 mins. The ionization voltage was $70 \mathrm{eV}$. It is separated into various constituents with different retention time which are detected by mass spectrophotometer. The chromatogram shows a plot of intensity against retention time was recorded by the software attached to it. The constituents were identified by comparing retention times of the GC peaks with those of reference compounds run under identical conditions and fragmentation patterns in mass spectra were matched with those of the NIST - 11 \& WILEY library and published mass spectra. ${ }^{12}$

\section{RESULTS AND DISCUSSION}

GC-MS analysis of the n-hexane extracts of the stem bark of S. crataegoides is given in Table 1. Fifty seven compounds were identified by comparison with the authentic spectra obtained from GC-MS library (NIST 11 and WILEY). Even though several peaks were present in the GC-MS chromatogram (Figure 2), the identification of only 57 constituents was established by comparison with the authentic spectra obtained from GC-MS library with the SI factor. Qualitative GC-MS analysis of n-hexane extract results revealed that Undecane (7.51\%, Figure $3 \& 4)$ was found as major compound. It is a liquid alkane hydrocarbon with the chemical formula $\mathrm{CH}_{3}(\mathrm{CH} 2)_{9} \mathrm{CH}_{3}$. It is reported as a mild sex attractant for various types of moths and cockroaches, and an alert signal for a variety of ants. ${ }^{13}$ It has 159 isomers. Isopropyl myristate is the ester of isopropanol and myristic acid was found second major compound in the extract of the plant $(7.45 \%$, Figure $5 \& 6)$. It is used in cosmetic and topical medicinal preparations where good absorption through the skin is desired. It is also used as a pesticide-free treatment against head lice which works by dissolving the wax that covers the exoskeleton of head lice, killing them by dehydration. Dodecane is present third major percentage present in the extract $(4.60 \%$, Figure $7 \& 8)$. It is a liquid alkane hydrocarbon with the chemical formula $\mathrm{CH}_{3}\left(\mathrm{CH}_{2}\right)_{10} \mathrm{CH}_{3}$, an oily liquid of the paraffin series. It has 355 isomers. Other compounds like 1,2,4-trimethyl-benzene (3.24\%), Octacosane (2.77\%), 2-methyldecane (2.28\%), 2-ethyl-1,2-dimethyl-benzene (2.01\%), 1, 2, 3, 5- tetramethyl-benzene $(2.00 \%)$, 1-chloro-heptacosane (1.86\%), Hentriacontane (1.72\%), Eicosane (1.71\%), Azulene (1.67\%), Tridecane (1.65\%), 3-methyl decane (1.57\%), 1-methyl-3-propyl benzene $(1.53 \%)$, Docosane (1.50\%), 1-bromo-octadecane (1.49\%), Tetracosane $(1.24 \%)$, Nonacosane (1.22\%), 3,6-dimethyl-undecane (1.21\%), 2-methyl-transdecalin (1.20\%), Mesitylene (1.18\%), Octadecane 91.14\%), O-cymene (1.00\%), 2-methyl-undecane (1.00\%) and 2,6-dimethyl-octane (0.99\%). The other compounds such as 1,3-diethyl-Benzene, 1-methyl-2-propylbenzene, 2-ethyl-1,4-dimethyl benzene, 4-ethyl-1,4-dimethyl-benzene, 1,2,3,4-tetramethyl-benzene, 3,7-dimethyl-decane, 1-methyldecahydronaphthalene, Pentyl- cyclohexane, 1,2-bis(1-methylethyl)-benzene, 4-methyl-undecane, 3-methyl-undecane, 2-methyl-naphthalene, Tetradecane, Pentadecane, Hexadecane, Heptadecane, Butyl myristate, Octatriacontyl pentafluoropropionate, Octadecanoic acid -2-methylpropyl ester, 2,6,10,14-tetramethyl-hexadecane, Tricosane, Heneicosane, 2-(octadecyloxy)-ethanol, 1-iodo-hexadecane, Nonahexacontanoic acid, 1-Hexacosene, Hexacosane, 1-iodo-octadecane, 1-bromodocosane and 11-cyclopentyl-heneicosane were found to 


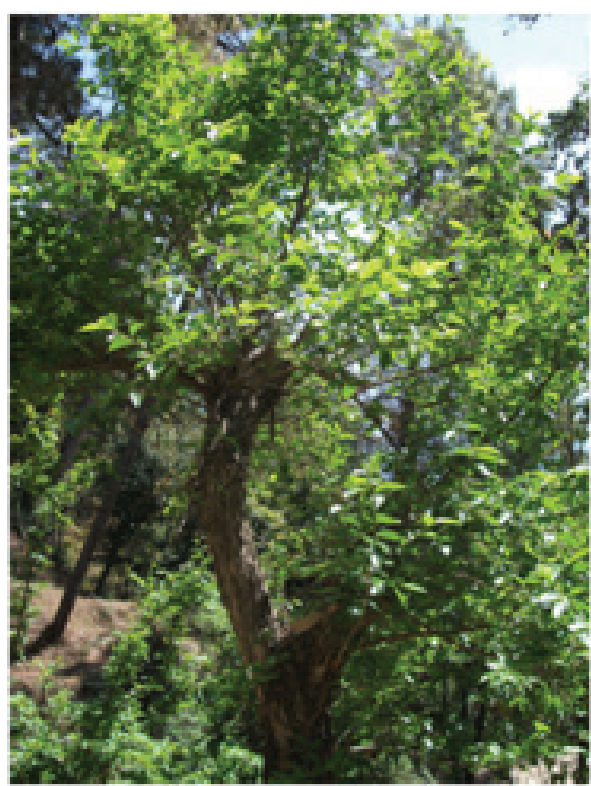

Natural Habit

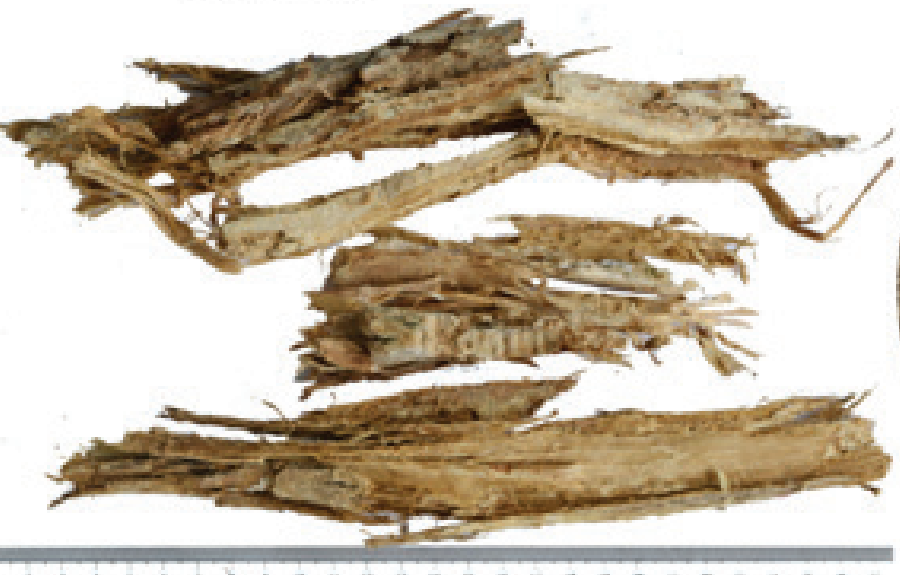

Dried Stem Barks

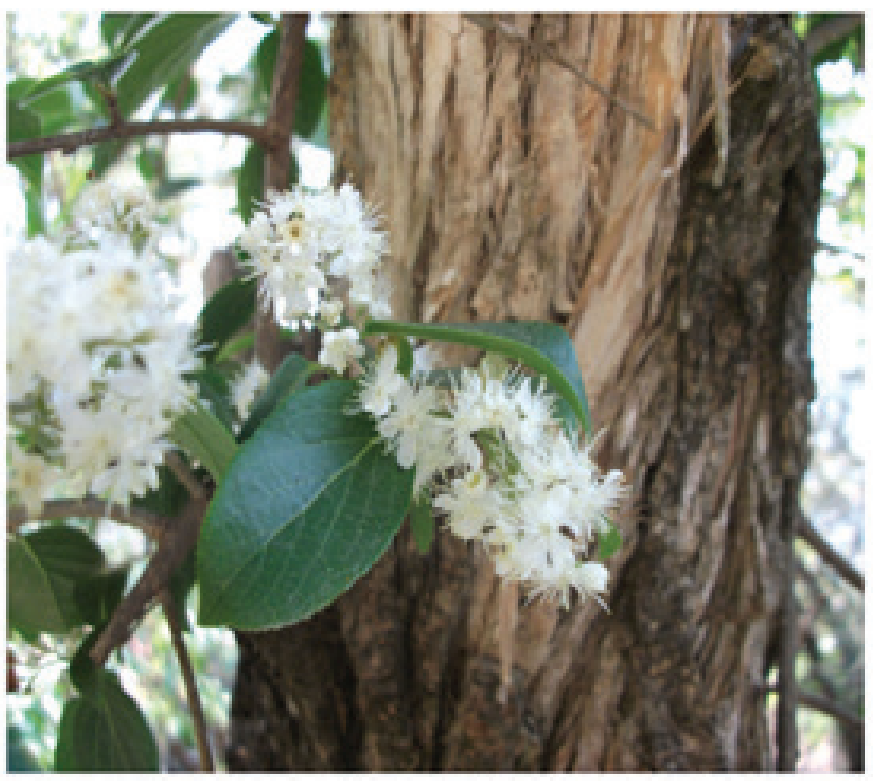

Flowering twig

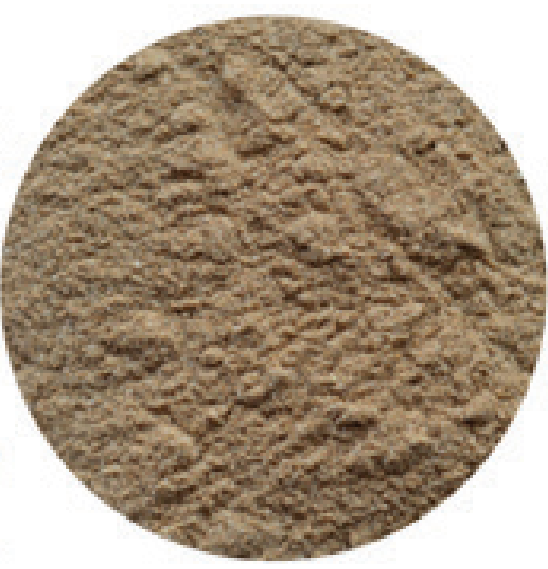

Powder

Figure 1: Symplocos crataegoides Buch.-Ham. ex D. Don

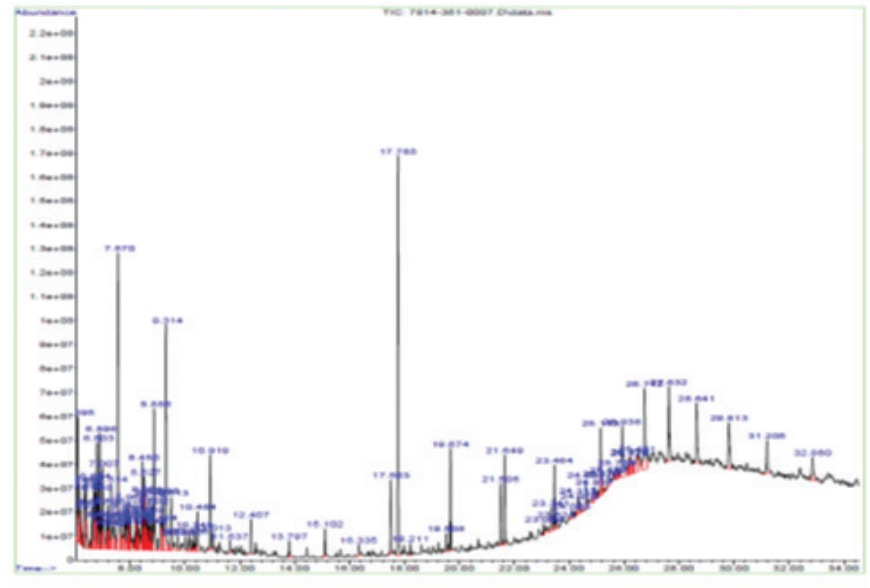

Figure 2: GC-MS Chromatogram of n-hexane extract of stem bark of S. crataegoides.

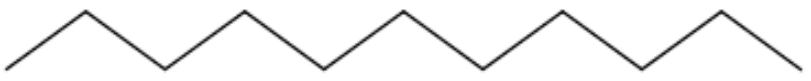

Figure 3: Undecane.

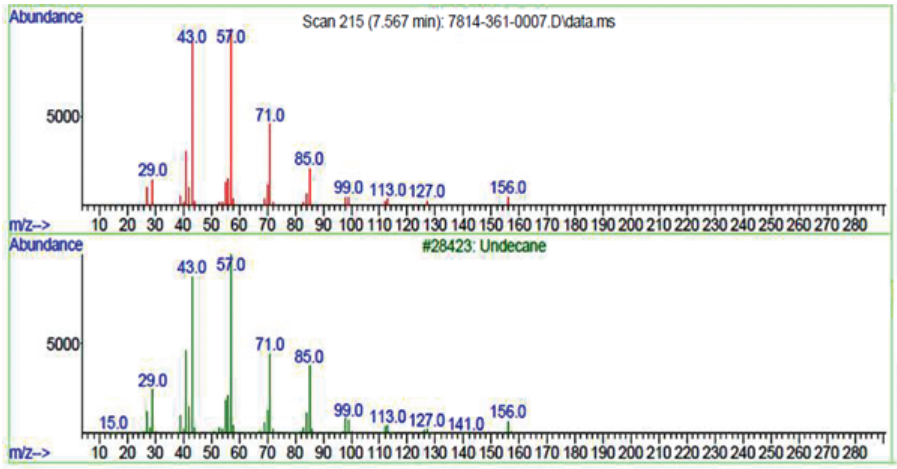

Figure 4: GC- MS Spectra of Undecane (Retention time -7.567). 


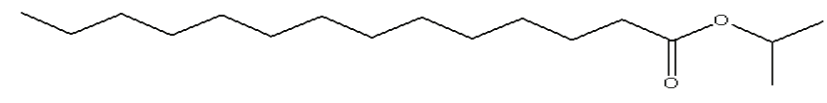

Figure 5: Isopropyl myristate.

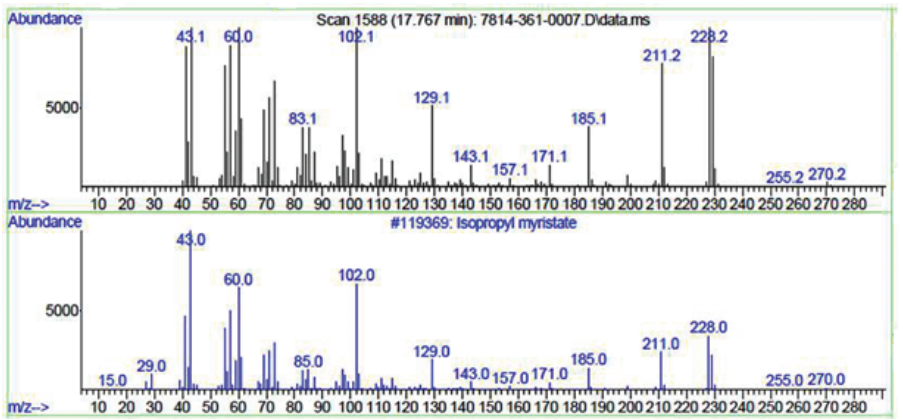

Figure 6: GC- MS Spectra of Isopropyl myristate (Retention time -17.767).

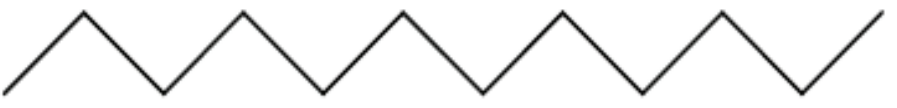

Figure 7: Dodecane.

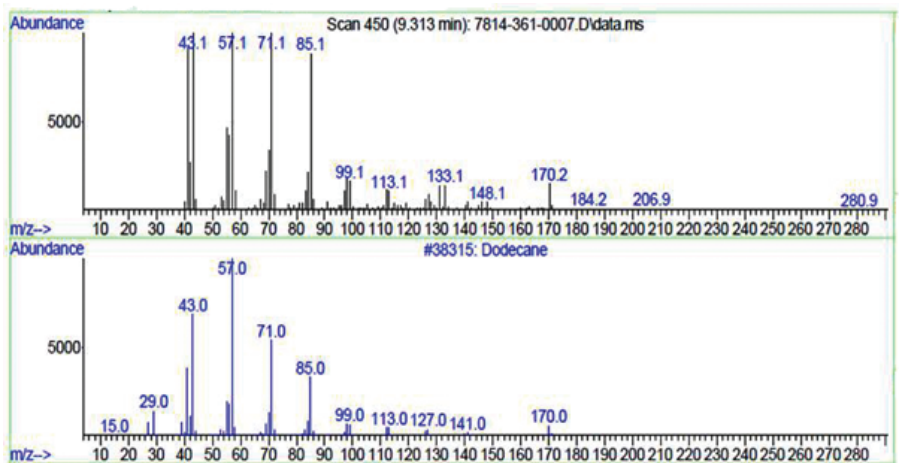

Figure 8: GC-MS Spectra of Dodecane (Retention time - 9.313).

be in small quantities. All the above 57 compounds were identified and reported for the first time from the stem bark of the plant.

\section{CONCLUSION}

In the present study fifty seven chemical constituents have been identified from n-hexane extract of the stem bark of $S$. crataegoides by Gas Chromatogram Mass Spectrometry (GC-MS) analysis. The presence of various phytochemicals contributes to the medicinal activity of the plant.

\section{ACKNOWLEDGEMENT}

The author are very grateful to the Director General, Central Council for Research in Ayurvedic Sciences, New Delhi, for his encouragement and providing opportunity to conduct this study.

\section{CONFLICT OF INTEREST}

The authors declare no conflict of interest.

\section{ABBREVIATIONS USED}

AR: Analytical Reagent; GC-MS: Gas chromatography and Mass spectroscopy; SI: Super Impossibility; $\boldsymbol{t}_{R}$ : Retention time.

\section{REFERENCES}

1. Anonymous. National Institute of Science Communication and Information Resources, CSIR, New Delhi, India; 1976 (Rep.2009);89-91.

2. Narayana Aiyer K, Namboodiri AN, Kolammal M. Pharmacognosy of Ayurvedic Drugs (Kerala), The Central Research Institute, University of Travancore. 1957;1 (3):65-74.

3. Jain SK. India - The Land and the People Medicinal Plants, National Book Trust, India; 1968.166-7.

4. Joshi SG. Medicinal Plants, Oxford and IBH Publishing Co. Pvt. Ltd., New Delhi; 2000.

5. Kirtikar KR, Basu BD. Indian Medicinal Plants, Vol. II, Second Edition. 1935 (Rep.1975); 1510-3.

6. Nadkarni AK, Dr. Nadkarni's KM. Indian Meteria Medica. Popular Prakashan 1954; 1186-8.

7. Kurup PNV, Ramadas VNK, Prajapati Joshi. Hand book of Medicinal Plants, Vol.1, 1977;135-6. PMCid:PMC421410.

8. Sivarajan VV, Indira Balachandran. Ayurvedic Drugs and their Plant Sources, Published by Mohan primlani for Oxford and IBH Publishing. 1994.

9. Anonymous. The Ayurvedic Formulary of India, Part-I, second revised English Edition, Govt. of India, Ministry of Health and Family Welfare, Dept. of Indian systems of Medicine \& Homoeopathy, New Delhi. 2003;57:112-3.

10. Kumar Naveen, Jangwan JS. Phytoconstituents of Symplocos paniculata (leaves). Journal of Current Chemical \& Pharmaceutical Science. 2012:2:76-80.

11. Semwal Ruchi Badoni, Semwal Deepak Kumar, Semwal Ravindra Singh, Randhir Rawat, Mohan Singh Maniyari. Chemical constituents from the stem bark of Symplocos paniculata Thunb. with antimicrobial, analgesic and antiinflammatory activities, J. Ethnopharmacol. 2011;135(1):78-87. http://dx.doi. org/10.1016/j.jep.2011.02.021. PMid:21354288. Adams RP. Identification of essential oils by gas chromatography/quadrupole mass spectroscopy. Illinois: Allured Publishing Corporation; 2001.

12. Holldobler B, Wilson EO. The Ants. Harvard University Press: 1990;287. http:// dx.doi.org/10.1007/978-3-662-10306-7 